\title{
FAKTOR PENDORONG DAN IMPLIKASI PERKEMBANGAN PARIWISATA SPIRITUAL DI KAWASAN PARIWISATA UBUD
}

\author{
I Wayan Putra Aditya \\ Universitas Udayana \\ Email: aditditya33@gmail.com \\ I Wayan Ardika \\ Universitas Udayana \\ Email: ardika52@yahoo.co.id \\ Ida Bagus Gde Pujaastawa \\ Universitas Udayana \\ Email: ibg_pujaastawa@yahoo.com
}

\begin{abstract}
The development of spiritual tourism activities in the Ubud Tourism Area based on the Tourism Area Life-Cycle Theory is at consolidation stage, which is seen from the many places that offer spiritual tourism activities both owned by local people and foreigners, resulting in price competition between these businesses.. The purpose of this research are to identify driving factors and implications of spiritual tourism development in the Ubud Tourism Area. This research is a qualitative descriptive study using observation and interviews for data collection methods. The theory used in this research are Contemporary Spiritual and Alternative Tourism Theory to explain the driving factors and implications sustainability resulting from spiritual tourism activities development related to. The driving factors include internal factors such as history and education as popular goals, external factors such as capitalism, world travel trends, and demand. Implications of this are implications for environmental, such as the conversion of residents' settlements and land conversion, for socio-cultural, such as changes in the consumption patterns of local people and revitalization of local spiritual activities, and for the economic, such as increased employment, increased income for spiritual service businesses, and increased ownership of local tourism businesses, where these implications require supervision by stakeholders so that they remain sustainable and provide optimal local communities benefits.
\end{abstract}

Keywords: Implications, Spiritual Tourism, Ubud Tourism Area. 


\section{Pendahuluan}

Aktivitas pariwisata dengan sentuhan budaya lokal semakin mengalami perkembangan melalui kegiatan keagamaan, kesenian dan bahkan praktik spiritual. Perkembangan aktivitas tersebut memberikan peluang dalam pelestarian lingkungan, sosial budaya dan pertumbuhan ekonomi masyarakat setempat. Dari ketiga kegiatan pariwisata tersebut, yang saat ini mulai diminati yakni aktivitas pariwisata spiritual yang menjadi salah satu bagian dari pariwisata tertua serta menjadi bagian pasar global dan perkembangannya signifikan. Salah satu kawasan pariwisata di Bali yang mengembangkan pariwisata spiritual adalah Kawasan Pariwisata Ubud. Perkembangan pariwisata spiritual di Kawasan Pariwisata Ubud yang saat ini menjadi sebuah trend berkunjung ke Ubud untuk melakukan aktivitas pariwisata spiritual, dikarenakan permintaan aktivitas pariwisata spiritual semakin meningkat. Aktivitas pariwisata spiritual yang dikembangkan sebagai atraksi pariwisata di Kawasan Pariwisata Ubud, dibagi menjadi empat, antara lain: Yoga, Spiritual Healing, Meditasi dan Aktivitas Puja.

Perkembangan pariwisata spiritual di Kawasan Pariwisata Ubud dikaitkan dengan teori Tourism Area Life Cycle, bahwa saat ini perkembangannya berada pada tahap konsolidasi (consolidation), yang pada tahap ini sektor pariwisata menunjukan dominasi dalam struktur ekonomi pada suatu kawasan dan ada kecenderungan dominasi jaringan internasional semakin kuat memegang peranannya pada kawasan destinasi tersebut. Kunjungan wisatawan masih menunjukan peningkatan yang cukup positif namun telah terjadi persaingan harga diantara perusahaan sejenis pada industri pariwisata di kawasan tersebut (Aditya, 2019). Berkaitan dengan perkembangan aktivitas pariwisata spiritual di Kawasan Pariwisata Ubud, dalam penelitian ini masalah yang dibahas berkaitan dengan faktor-faktor pendorong perkembangan aktivitas spiritual dan implikasi yang ditimbulkan akibat perkembangan aktivitas pariwisata spiritual di Kawasan Pariwisata Ubud. 


\section{Teori dan Metode}

Teori yang digunakan dalam penelitian ini adalah Teori Spiritualitas Kontemporer dan Teori Pariwisata Alternatif. Teori Spritualitas Kontemporer sejatinya memperlihatkan kontradiksi kultural, yakni di satu pihak menawarkan jalan pencerahan jiwa, sedangkan di pihak lain dapat menjerumuskan pada perangkap gaya hidup. Dengan demikian, spiritualitas pada masyarakat kontemporer adalah bagian dari gaya hidup. Kapitalisme global mengkonstruksi berbagai macam gaya hidup dan melahirkan masyarakat konsumer yang sangat bergantung pada irama pergantian gaya, citra, dan status yang ditawarkan. Dalam dunia konsumerisme, apapun dapat dikonstruksi sebagai bagian dari gaya hidup, tidak terkecuali spiritualitas, selama ia dapat diubah menjadi citra, tanda, dan gaya. Simbiosis antara gaya hidup dan spiritualitas telah menciptakan kondisi di mana manusia terperangkap ke dalam dunia paradok yang mencampuradukkan antara gaya hidup yang bersifat duniawi dan spiritualitas yang bersifat sakral. Bahkan halhal yang bersifat spiritual seperti yoga, tenaga dalam, puasa, doa, dan lainnya kini menjadi bagian dari gaya hidup masyarakat. Di dalam wacana pospiritualitas, segala sesuatu yang bersifat profane kini tumpang tindih dengan hal-hal yang bersifat transendental atau sakral (Piliang, 2004). Teori kedua yaikni Teori Pariwisata Alternatif merupakan suatu bentuk pariwisata yang lebih mengutamakan kelestarian alam, sosial dan nilai-nilai yang dianut masyarakat lokal. Melalui pariwisata alternatif juga memungkinkan masyarakat lokal dan wisatawan menikmati interaksi yang positif dan bermanfaat serta menikmati pengalaman secara bersama-sama (Eadington dan Smith, 1992:3). Jadi dalam pandangan ini ada beberapa kunci penting dari kegiatan pariwisata alternatif yaitu:

a. Pariwisata yang mementingkan nilai-nilai alam.

b. Pariwisata yang mementingkan nilai-nilai sosial budaya

c. Adanya manfaat yang dapat dinikmati secara bersama oleh masyarakat secara ekonomi. 
Lebih lanjut Smith memberikan pandangan tentang pariwisata alternatif sebagai pariwisata yang dapat memberikan sesuatu yang berbeda dengan pariwisata konvensional yang identik dengan pariwisata massal. Kegiatan wisata massal yang banyak menyebabkan masalah seperti kebisingan, polusi, dan hal-hal negatif lainnya.

Kegiatan-kegiatan pariwisata alternatif dapat berupa kegiatan mempelajari kehidupan sosial budaya masyarakat lokal seperti belajar menari, bahasa, memasak makanan lokal, jalan-jalan menikmati keindahan suasana kehidupan alam pedesaan dan kegiatan wisata yang jauh dari suasana bising dan polusi (Eadington dan Smith, 1992: 135).

Penelitian ini berlokasi di Kawasan Pariwisata Ubud, Kecamatan Ubud, Kabupaten Gianyar, Provinsi Bali. Penelitian ini berfokus pada pusat-pusat kegiatan pariwisata spiritual, seperti ashram, pusat meditasi, tempat retreat, dan rumah healer (Balian). Lokasi ini dipilih karena Kawasan Pariwisata Ubud merupakan salah satu kawasan yang selain terkenal sebagai kawasan pariwisata budaya juga dikenal sebagai tempat yang menyediakan banyak keterkaitan dengan spiritual, seperti contoh mendiang I Ketut Liyer yang disebut sebagai healer (Balian) dalam novel Eat Pray Love (2006) karya Elizabeth Gilbert. Hal ini tentu menjadikan Ubud tidak hanya terkenal dengan kebudayaan tradisional tetapi juga terkenal sebagai daerah yang menjadi tujuan bagi para penikmat pariwisata spiritual. Pemilihan lokasi ini disesuaikan dengan kebutuhan data dalam rumusan masalah. Teknik pengumpulan data yakni menggunakan observasi dan wawancara dengan analisis deskriptif kualitatif. 


\section{Pembahasan}

\section{Faktor-Faktor Pendorong Perkembangan Pariwisata Spiritual di Kawasan Pariwisata Ubud}

Adapun faktor-faktor yang mempengaruhi perkembangan pariwisata spiritual di Kawasan Pariwisata Ubud yakni dibedakan menjadi dua, antara lain faktor internal dan faktor eksternal.

\section{a. Faktor Internal}

Faktor internal dalam perkembangan pariwisata spiritual di Kawasan Pariwisata Ubud telah dibagi menjadi dua faktor yaitu (1) Faktor Historis Ubud, dilihat dari sejarah atau historis Ubud melalui perjalanan Rsi Markandeya yang melakukan semadi dan yoga dengan membuka hutan dan membangun Pura Gunung Lebah di areal bukit Campuhan. Hal ini juga terkait dengan nama Ubud yang dulunya berasal dari kata Ubad yang artinya penyembuhan. (2) Faktor Ubud sebagai Destinasi Populer, Ubud yang terkenal sebagai destinasi wisata populer dunia menjadi salah satu faktor yang sangat kuat dalam mendorong perkembangan pariwisata spiritual di kawasan pariwisata Ubud. Dengan banyaknya kunjungan wisatawan dan tingginya pencarian informasi tentang Ubud oleh calon wisatawan sangat memudahkan dalam memperkenalkan aktivitas pariwisata spiritual.

\section{b. Faktor Ekternal}

Faktor eksternal dalam perkembangan pariwisata spiritual di Kawasan Pariwisata Ubud telah dibagi menjadi tiga faktor yaitu (1) Faktor Kapitalisme, terjadinya perkembangan pariwisata spiritual di Kawasan Pariwisata Ubud tidak dapat dipungkiri sebagai akibat dari faktor perkembangan masyarakat kearah masyarakat industri yang lebih cenderung memiliki tujuan kearah ekonomi. Aktivitas spiritual yang dilakukan masyarakat bahkan hanya dilakukan untuk 
meraih keuntungan. Sama halnya juga dengan pandangan Mark Weber (dalam Soekanto: 2009) bahwa ide-ide dan gagasan telah menjadi suatu refleksi kepentingan material terutama kepentingan ekonomi. (2) Faktor Trend Wisata Dunia, terjadinya pergeseran dari "sun, sand, and sea" menjadi "serenity, sustainability and spirituality". Berdasarkan penelitian, bahwa dalam kurun waktu 2005 sampai 2010 terjadi kenaikan hingga $165 \%$ atas perjalanan wisata yang didasarkan pada keyakinan diri (faith based). UNWTO (2010) memperkirakan sekitar 330 juta wisatawan global atau kurang lebih 30\% dari total keseluruhan wisatawan global melakukan kunjungan ke situs-situs religious penting di seluruh dunia, baik didasarkan pada motif spiritual ataupun motif kognitif (Sunarta dan Arida, 2017). Sesuai dengan adanya pergesaran tersebut menjadikan salah satu faktor pendorong dalam perkembangan pariwisata spiritual di Kawasan Pariwisata Ubud, bahwa halnya motif perjalanan seperti ini, biasanya wisatawan asing melakukan perjalanan ke timur untuk mencari sebuah ketenangan dengan malakukan praktik spiritual lintas agama. (3) Faktor Permintaan, Aktivitas pariwisata spiritual mengalami perkembangan yang tidak hanya melalui produk spiritual yang ditawarkan, namun dalam hal ini meningkatnya permintaan wisatawan juga menjadi salah satu faktor pendorong dalam perkembangannya. Wisatawan dengan motivasi melakukan wisata minat khusus biasanya memiliki motivasi perjalanan dengan tujuan mencari peace and harmony. Seiring dengan perkembangan teknologi penggunaan media internet dalam perkembangan pariwisata spiritual selain sebagai media promosi, internet seperti Facebook, TripAdvisor dll digunakan sebagai media untuk menampung komentar dari wisatawan yang akan melakukan dan wisatawan yang sudah melakukan aktivitas spiritual, tujuannya agar penyedia jasa spiritual mengetahaui permintaan wisatawan yang akan melakukan aktivitas spiritual, dan begitu juga sebaliknya untuk membagikan pengalaman spiritual bagi teman-teman wisman yang sudah pernah melakukan aktivitas spiritual. 


\section{Implikasi Perkembangan Pariwisata Spiritual di Kawasan Pariwisata Ubud}

Berkembangnya pariwisata spiritual yang saat ini menjadi trend berwisata di kawasan pariwisata Ubud menimbulkan sejumlah implikasi yang terkait dengan keberadaan aspek lingkungan, aspek sosial budaya dan ekonomi masyarakat Ubud.

\section{a. Implikasi Terhadap Aspek Lingkungan}

Sesuai dengan analisis yang telah dilakukan dalam perkembangan pariwisata spiritual di kawasan pariwisata Ubud, telah terjadinya implikasi terhadap aspek lingkungan, yang dijabarkan sebagai berikut.

\section{Alih Fungsi Permukiman Warga Sebagai Usaha Pariwisata}

Kegiatan pariwisata spiritual yang saat ini dilakukan di kawasan pariwisata Ubud tidak hanya dilakukan seperti biasanya di hotel ataupun di tempat khusus untuk yoga, namun dalam perkembangan aktivitas spiritual saat ini masyarakat yang mempunyai keahlian di bidang spiritual memanfaatkan rumahnya sebagai tempat untuk melakukan aktivitas pariwisata spiritual. Pemanfaatan pemukiman atau rumah sebagai fasilitas tempat dalam praktik spiritual dari dulu sudah dilakukan oleh mendiang Ketut Liyer, hal ini juga dilakukan serupa saat ini oleh Arsana dan Sumantra.

Sesuai dengan observasi langsung, rumah Arsana mempunyai bangunan dengan arsitektur khas Bali, yang mana tata letak bangunan menggunakan ukuran sesuai pemetaan bangunan Bali, dengan istilah balinya "sikut satak". Menurut hasil wawancara dengan Arsana (wawancara, 8 Oktober 2018) bahwa keputusan beliau memilih konsep arsitektur Bali dikarenakan rumahnya terletak di lokasi yang mempunyai adat dan kebudayaan yang sangat kuat, maka dari itu beliau tidak mau menghilangkan kesan-kesan yang bernuansa Bali di Rumahnya. Adapun bangunan rumah Arsana seperti pada gambar berikut 


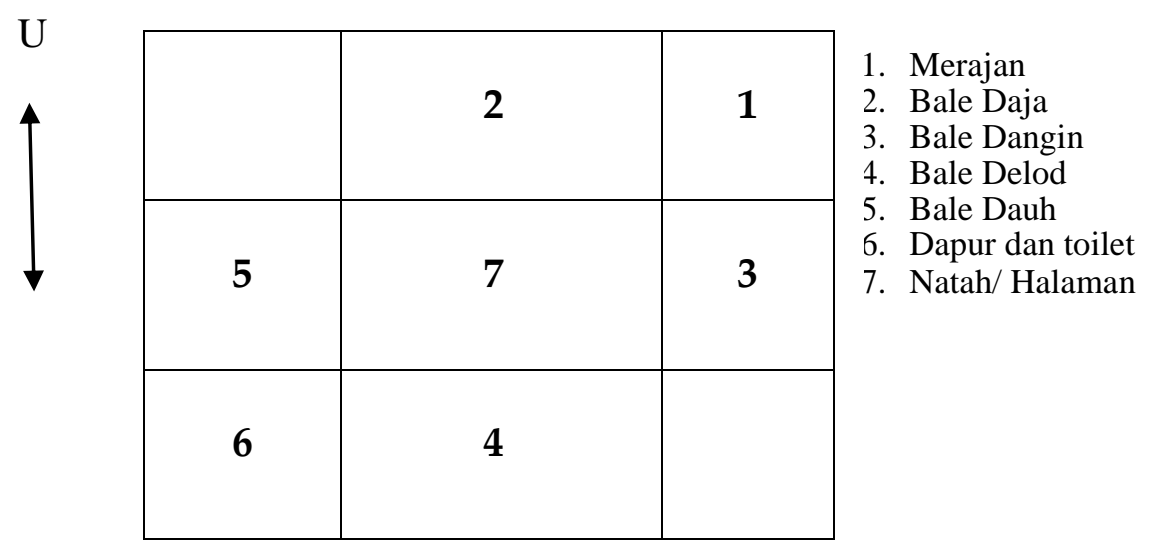

Gambar 1: Denah Rumah Ketut Arsana

Sumber : Hasil Observasi, 2018

Adapun penjelasan mengenai denah rumah tersebut yakni: (1) Sanggah (Pura keluarga) merupakan tempat persembahyangan untuk orang yang tinggal di lingkungan rumah tersebut. Jika dilihat dari sisi spiritual Sanggah merupakan suatu titik spiritual yang ada di rumahnya. Fungsi Sanggah digunakan sebagai tempat melakukan puja kepada tuhan siva bagi para wisatawan yang melakukan meditasi di rumah Arsana; (2)"Bale Daja”, merupakan bangunan di posisi Utara dengan fungsi sebagai tempat untuk rapat keluarga bagi orang bali, pada rumah Arsana, Bale Daje juga digunakan sebagai tempat untuk melakukan konsultasi sebelum melakukan yoga di studio yoga yang sudah disediakan; (3) "Bale Dangin", merupakan bangunan di posisi timur, yang dimana bangunan ini memiliki fungsi untuk melakukan kegiatan upacara seperti potong gigi, menikah, dan kematian; (4) "Bale Delod", merupakan bangunan yang berada pada posisi Selatan. Bale Delod dibangun dua lantai yang berfungsi sebagai studio untuk melakukan kelas yoga; (5) "Bale Dauh", merupakan bangunan yang berada di posisi barat yang difungsikan sebagai bale keluarga dari Arsana; (6) Dapur dan toilet yang berada pada posisi pojok selatan barat yang difungsikan sebagai toilet dan tempat untuk membuatkan minuman atau makanan yang di request oleh wisatawan; (7) Natah atau halaman 
rumahnya difungsikan sebagai tempat untuk melakukan tarian-tarian (dance) yang dilakukan oleh wisatawan yang melakukan kegiatan spiritual di rumahnya.

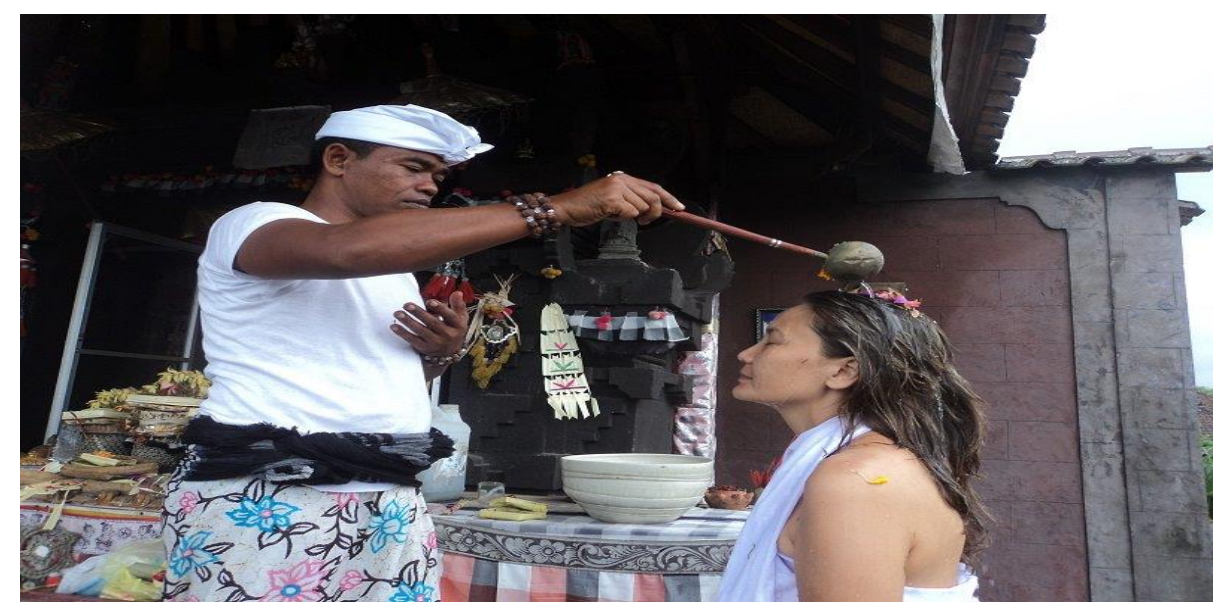

Gambar 2. Aktivititas spiritual lokal yang dilakukan dirumah Guru Made Sumantra

\section{Pelestarian Lingkungan}

Lahan perkebunan dan sawah di Ubud pada awalnya digunakan sebagai daya tarik wisata alam, yang dimana wisatawan yang berkunjung ke Ubud dapat menikmati keindahan sawah dan kebun sambil melakukan kegiatan trekking maupun bersepeda keliling Ubud. Seiring perkembangan pariwisata yang begitu pesat di Ubud saat ini lahan sawah dan kebun sudah sebagian didirikan hotel-hotel megah dengan standar internasional yang menggunakan pemandangan alam Ubud yang berupa sawah, kebun maupun sungai Ubud sebagai daya tarik dalam perkembangan industri perhotelan di kawasan Ubud.

Dalam perkembangan jenis pariwisata spiritual mampu membawa pengaruh berkelanjutan secara ekologis, karena tidak menimbulkan efek negatif bagi ekosistem di Kawasan Pariwisata Ubud. Melainkan, kegiatan pariwisata ini berupaya untuk memelihara kelestarian alam misalnya dengan cara pemeliharaan tumbuh-tumbuhan yang berkhasiat untuk pengobatan dan kesehatan tradisional 
dan memanfaatkan alam sebagai media mencari ketenangan dalam melakukan aktivitas spiritual.

\section{b. Implikasi Terhadap Aspek Sosial Budaya}

Sesuai dengan analisis yang telah dilakukan dalam perkembangan pariwisata spiritual di kawasan pariwisata Ubud, telah terjadinya implikasi terhadap aspek sosial budaya, yang dijabarkan sebagai berikut.

1. Perubahan Pola Konsumsi Masyarakat Lokal Terhadap Aktivitas Pariwisata Spiritual

Perkembangan pariwisata spiritual di Kawasan Pariwisata Ubud, ternyata tidak hanya berpengaruh terhadap pola perjalanan dan konsumsi wisatawan. Berkembangnya spiritual saat ini menjadi kemasan spiritual product juga mempengaruhi pola konsumsi masyarakat lokal khususnya masyarakat Ubud terhadap aktivitas spiritual. Berkembangnya beragam kemasan spiritual product juga menarik minat masyarakat lokal untuk turut serta mengkonsumsi atau menggunakannya sebagai salah satu aktivitas kesehatan mereka.

\section{Revitalisasi Aktivitas Spiritual Lokal}

Adanya modifikasi terhadap aktivitas spiritual Bali dengan luar sebagai daya tarik spiritual tourism secara tidak langsung juga telah menjadi upaya untuk menggali kembali pengetahuan tradisional dalam bidang kesehatan. Perkembangan aktivitas spiritual yang dilakukan oleh para praktisi untuk dijadikan sebagai kemasan wisata juga telah memberikan pengaruh besar terhadap kepedulian masyarakat kepada eksistensi spiritual lokal. Walaupun dengan adanya modifikasi ini masyarakat lebih banyak mengenal bentuk baru dari hasil kemasan dibandingkan dengan bentuk aslinya. 


\section{c. Implikasi Terhadap Aspek Ekonomi}

Sesuai dengan analisis yang telah dilakukan dalam perkembangan pariwisata spiritual di kawasan pariwisata Ubud, telah terjadinya implikasi terhadap aspek ekonomi, yang dijabarkan sebagai berikut.

\section{Peningkatan Lapangan Kerja}

Mata pencaharian masyarakat Kawasan Pariwisata Ubud terdiri berbagai jenis profesi salah satunya bergerak di bidang industri pariwisata. Sejak pariwisata berkembang sebagian besar masyarakat telah menggantungkan mata pencahariannya pada sektor ini di antaranya sebagai pelaku bisnis pariwisata, pelukis, seniman tari, pedagang souvenir maupun sebagai tenaga kerja pada akomodasi wisata. Terjadinya trend perkembangan pariwisata spiritual di kawasan pariwisata Ubud kini juga telah menambah kesempatan dan lapangan pekerjaan bagi masyarakat.

Dengan munculnya kegiatan pariwisata ini masyarakat telah memiliki kesempatan lebih besar untuk terlibat langsung di dalamnya baik sebagai pemilik, pengelola maupun pekerja pada pusat-pusat aktivitas pariwisata spiritual. Masyarakat juga berkesempatan untuk mengembangkan dan menjadi pemilik tempat-tempat aktivitas spiritual. Biaya dan modal untuk penyediaan tempat kegiatan pariwisata ini tidak terlalu besar dan terjangkau bagi masyarakat lokal. Hal terpenting adalah masyarakat harus memiliki keterampilan di bidang wisata spiritual dan jika ingin mendirikan studio yoga atau ashram dapat dimulai dari tingkat yang lebih kecil dan dikembangkan secara bertahap. Seperti cerita yang dituturkan oleh praktisi sekaligus pemilik dari Ashram Munivara yaitu Ketut Arsana (wawancara 20 Oktober 2018) bahwa ia juga memulai usahanya dengan tempat kecil yaitu menggunakan rumahnya sendiri. Tetapi seiring dengan perjalanan waktu dan semakin dikenalnya aktivitas spiritual miliknya oleh wisatawan akhirnya Arsana berkembang menjadi besar seperti saat sekarang. 
Implikasi dari perkembangan pariwisata spiritual terhadap kesempatan dan lapangan pekerjaan juga banyak dirasakan oleh masyarakat luas terutama para generasi muda. Aktivitas pariwisata ini telah memberikan peluang besar bagi masyarakat untuk menjadi tenaga kerja pada tempat-tempat usaha jasa spiritual seperti studio yoga maupun Ashram di kawasan Ubud. Kesempatan kerja yang terbuka bagi masyarakat di antaranya sebagai yoga instructure maupun sebagai healer. Hal yang sama juga dikemukan oleh Putra (wawancra 4 November 2018) yang dimana awalnya ia sebagai instruktur yoga di Yoga Barn, dan seiring dengan bertambahnya permintaan wisatawan untuk melakukan yoga, saat ini ia mengajar yoga ke hotel-hotel maupun private yoga melalui murid langganannya.

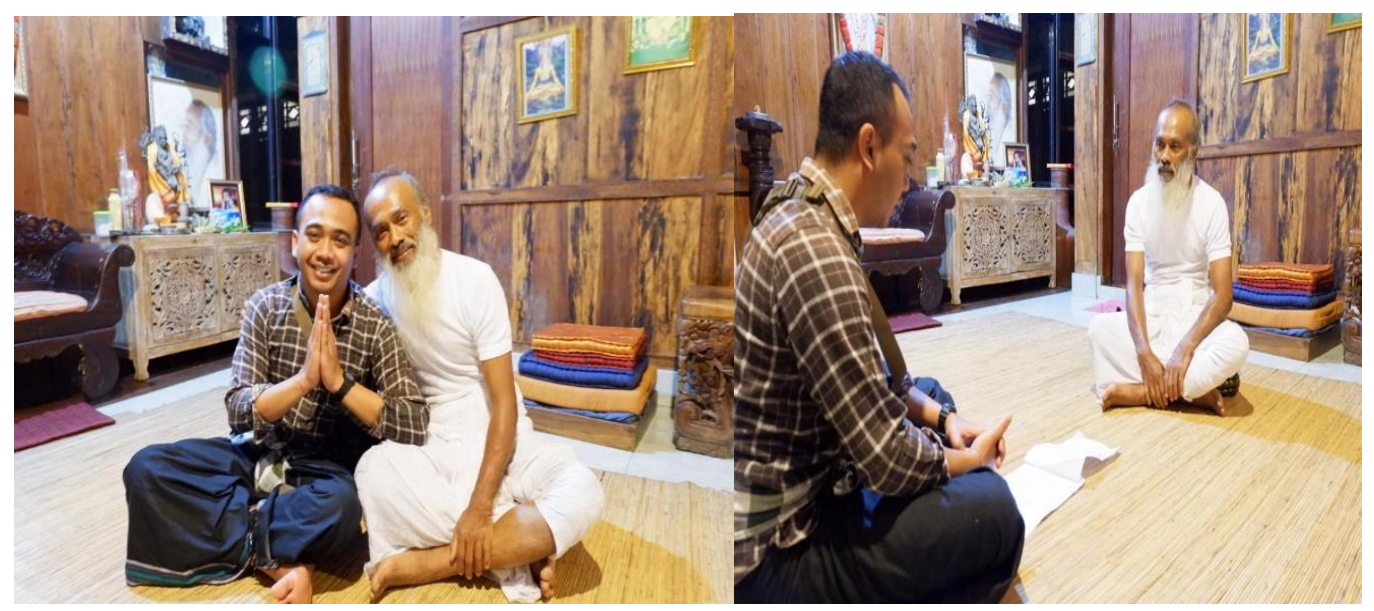

Gambar 3. Wawancara bersama Guru I Ketut Arsana Sumber: Peneliti.

\section{Meningkatnya Pendapatan Pelaku Usaha Jasa Spiritual}

Kegiatan pariwisata akan membawa pengaruh terhadap pendapatan masyarakat di sekitarnya. Semakin berkembangnya pariwisata maka pengaruh yang diberikan kepada masyarakat terutama para pelaku pariwisata akan semakin besar. Perkembangan pariwisata juga dapat merangsang masyarakat sekitar untuk mengembangkan potensi yang mereka miliki salah satunya dengan menjadikan produk budaya lokal sebagai komoditas bisnis pariwisata. 
Perkembangan pariwisata spiritual yang terjadi di Kawasan Pariwisata Ubud juga memberikan implikasi yang sangat signifikan terhadap pendapatan masyarakat terutama bagi mereka yang terlibat langsung dalam aktivitas pariwisata spiritual. Seperti yang disampaikan oleh Putra (wawancara 4 November 2018) bahwa pemasukan dari kerjanya sebagai instruktur yoga di Ubud sangat membantu dalam memenuhi kebutuhan sehari-harinya. Hal ini berkaitan dengan pembagian hasil dari pelaksanaan aktivitas yoga di Yoga Barn, dengan persentase pembagian sebesar 70 persen untuk guru yoga dan 30 persen untuk perusahaan. Dimana rata-rata biaya untuk melakukan aktivitas yoga sebesar Rp. 110.000 per orang, dengan rata-rata jumlah peserta yoga dalam satu studio sekitar 15 sampai 20 orang peserta. Sehingga rata-rata pendapatan per satu kelas studio yoga, Rp. 1.650 .000 per satu kali aktivitas yoga dengan pembagian Rp. 1.155.000 untuk guru yoga dan Rp. 495.000 untuk perusahaan.

\section{Meningkatnya Kepemilikan Usaha Lokal Pariwisata}

Kesempatan untuk melebarkan sayap terciptanya pada peluang kepemilikan usaha bagi masyarakat lokal kini kian semakin meningkat. Healer yang sebelumnya hanya melayani masyarakat lokal, kini berkembang menjadi pengusaha di bidang pariwisata spiritual maupun di bidang pariwisata lainnya. Arsana, Sumantra dan Nuriasih merupakan contoh-contohnya yang sampai saat ini (2018) memiliki usahausaha pariwisata. Arsana yang berawal dari healer lokal saat ini sudah bisa mengembangkan usahanya dengan memiliki ashram, studio yoga dan hotel. Begitu juga pada Sumantra yang mengembangkan usahanya mulai dari aktivitas spiritual dirumahnya lengkap dengan menyediakan Guest House untuk wisatawan yang ingin langsung menginap dan saat ini beliau juga sudah mulai mengembangkan sekolah Yoga "Markandeya Yoga School” untuk mendidik calon-calon guru yoga yang mempunyai sertifikasi. 
Perkembangan pariwisata spiritual di kawasan pariwisata Ubud menimbulkan implikasi terhadap meningkatnya kepemilikan usaha lokal yang tidak hanya melalui usaha terfokus kepada aktivitas spiritual. Menurut salah satu pengelola villa di lingkungan SokWayah Ubud, I Wayan Beli Artha (wawancara 9 Semptember 2018) bahwa semenjak berkembangnya aktivitas spiritual salah satunya yoga, sangat berpengaruh terhadap jumlah hunian dan lama tinggal wisatawan di villa, hotel maupun penginapan yang berada di Ubud khususnya lingkungan Sok Wayah. Artha mengatakan ditempatnya rata-rata wisatawan yang menginap adalah murid-murid yoga dari Yoga Union dan Akhasa Yoga yang mengikuti kelas yoga dengan durasi 100 sampai 200 jam. Hal ini menyebabkan lama tinggal wisatawan berkisar rata-rata seminggu sampai tiga minggu.

Berkembangnya usaha jasa spiritual di kawasan pariwisata Ubud dengan karakter wisatawan yoga melalui pola hidup sehat memberikan peluang bagi kepemilikan usaha lokal yang bergerak pada bidang food and beverage. Seperti yang dikemukan oleh salah satu pengelola restaurant vegetarian di Jl. Hanoman Ubud, Made Putri Indra (Wawancara 6 November 2018) bahwa dengan banyaknya penyediaan tempat yoga di Ubud yang mendatangkan wisatawan dengan tujuan yoga, biasanya mereka memilih tempat makan vegetarian. Selain itu, perkembangkan pariwisata spiritual juga berkontribusi kepada masyarakat yang menjual perlengkapan upacara sperti banten pejati, dupa dll.

\section{Simpulan dan Saran}

Berdasarkan uraian tersebut, disimpulkan bahwa perkembangan pariwisata spiritual di Kawasan Pariwisata Ubud menimbulkan implikasi terkait dengan lingkungan, sosial budaya dan ekonomi. Perkembangan ini mempunyai pengaruh dalam aspek lingkungan seperti alih fungsi pemukiman yang dimana rumah penduduk dikemas dan dijadikan prospek bisnis aktivitas spiritual dan berpengaruh terhadap alih fungsi lahan yang berdampak positif, kegiatan pariwisata ini berupaya 
untuk memelihara kelestarian alam. Dari aspek sosial telah mempengaruhi pola konsumsi aktivitas spiritual oleh masyarakat lokal, sedangkan dari aspek budaya, perkembangan pariwisata spiritual ini mampu menjadi langkah dalam merevitalisasi kembali budaya masyarakat terutama di bidang spiritual lokal. Hal ini juga berpengaruh terhadap perkembangan ekonomi, seperti pedagang pemasok barang-barang kebutuhan aktivitas spiritual. Bahkan perkembangan ini juga mampu membuka peluang kerja dan usaha bagi masyarakat sehingga saat ini banyak sekali masyarakat Ubud yang mengembangkan usaha di bidang pariwisata spiritual.

Dalam artikel ini, terdapat saran yang dapat dijadikan saran, yakni perlu ada peraturan terhadap alih fungsi lahan yang terus mangalami pemangkasan lahan dikarenakan kebutuhan industri pariwisata, kareana semakin berkurangnya lahan sawah dan kebun di Ubud akan secara tidak langsung akan berdampak pada daya tarik ubud sebagai lokasi pencarian spiritual. Pemerintah Kabupaten Gianyar juga hendaknya mendata tempat atau pusat aktivitas spiritual di kawasan pariwisata Ubud, agar dapat mengetahui pertumbuhannya.

\section{Daftar Pustaka}

Hasanah, Sekar, dkk. 2016. Alih Fungsi Lahan Sawah Subak ke Lahan Terbangun di Kelurahan Ubud Kecamatan Ubud Kabupaten Gianyar Bali. Tesis. Yogyakarta: Universitas Gadjah Made.

Narottama, Nararya. 2012. “Wisata Spiritual: Studi Kasus Partisipasi Orang Asing Dalam Upacara Pitrayajna di Desa Pakraman Muncan, Selat, Karangasem, Bali". (Tesis) Universitas Udayana. Denpasar.

Piliang, Yasraf Amir. 2004. Posrealitas, Realitas Kebudayaan dalam Era Posmetafisika. Bandung: Jalasutra.

Putra Aditya, I Wayan. 2019. "Perkembangan Pariwisata Spiritual di Kawasan Pariwisata Ubud". (Tesis). Universitas Udayana. Denpasar.

Smith, Valene L. and Eadington, William R. 1992. Tourism Alternatives Potentials and Problems in the Development of Tourism. England: Wiley \& Sons Ltd. 
Sutarya, I Gede. 2016. “Spiritual Healing dalam Pariwisata Bali: Analisis Tentang Keunikan, Pengembangan, dan Kontribusinya dalam Pariwisata". Disertasi. S3 Pariwisata. Universitas Udayana. Denpasar.

Suteja, I Wayan. 2016. “Komodifikasi Pengetahuan Tradisional Dalam Bidang Kesehatan Sebagai Daya Tarik Wellness Tourism di Kawasan Pariwisata Ubud". Tesis. Fakultas Pariwisata. Universitas Udayana. Denpasar

\section{Profil Penulis}

I Wayan Putra Aditya, S.Par.,M.Par merupakan lulusan linier dari Program Studi Sarjana di Fakultas Pariwisata Universitas Udayana dan ia menempuh studi lanjut pada Program Studi Magister Pariwisata Universitas Udayana angkatan 2016. Ketertarikannya pada bidang ilmu pariwisata dirasakannya semenjak pernah bekerja pada salah satu bidang industri perjalanan wisata di Bali. Ia saat ini berprofesi menjadi Dosen Pariwisata.

I Wayan Ardika dilahirkan di Tabanan, Bali 18 Februari 1952, merupakan salah satu Guru Besar bidang arkeologi pada Fakultas Sastra. Prof. Dr. I Wayan Ardika, M. A. menduduki jabatan Dekan Fakultas Pariwisata (1999-2001), kemudian menjabat sebagai Dekan Fakultas Sastra Unud (dalam dua kali jabatan 2003-2011). Lulusan Sarjana Arkeologi Universitas Udayana (1979), Master Prehistory, Canberra, Australia National University (1987), dan Doktor Prehistory di tempat yang sama tahun (1992). Kelompok Ahli Pembangunan Provinsi Bali Bidang Sosial Budaya (2000-2009).

Dr. Drs. Ida Bagus Gde Pujaastawa, MA. Adalah dosen antropologi Fakultas Ilmu Budaya, Universitas Udayana. Beliau menyelesaikan Pendidikan S-1 Ilmu Antropologi di Fakultas Sastra Universitas Udayana pada tahu 1996, S-2 Ilmu Antropologi di Universitas Indonesia pad atahun 2001, dan Pendidikan S-3 Kahian Budaya Universitas Udayana di tahun 2011. Beliau mengajar beberapa mata kuliah di Program S-2 Magister Pariwisata, S-2 Ilmu Lingkungan, S-2 dan S-3 Kajian Budaya Universitas Udayana. 